\title{
'An Alliance Forged in Blood': The American Occupation of Korea, the Korean War, and the US-South Korean Alliance
}

\author{
WILLIAM STUECK* AND BORAM YI** \\ *University of Georgia, USA, **University of Baltimore, USA
}

\begin{abstract}
The US occupation of Korea from 1945 to 1948 was not notable for its success. The volatile interaction between the occupiers and the occupied provided an important context for its relatively rapid conclusion and for Washington's ineffective employment of deterrence in the lead-up to the June 1950 North Korean attack on South Korea. This essay describes the volatile interaction between Americans and Koreans on the peninsula and the circumstantial, psychological, and cultural factors behind it. The essay concludes by analyzing the psychological impact of the Korean War on the relationship and how this and later cultural changes have made possible an enduring alliance between the United States and the Republic of Korea.
\end{abstract}

KEY WordS: US-South Korean Alliance, American Occupation, Korean War

Concluded in the immediate aftermath of the Korean War, the alliance of the United States with the Republic of Korea (ROK) is now over a half-century old. It has survived by a generation the end of the Cold War, the ROK rapprochement with Russia and China, and the ROK's rise as a regional power. It has endured the tremors created by the emergence in Korea of a generation with no direct memory of the Korean War, the simultaneous tenure in office of ham-handed leaders George W. Bush and Roh Moo-hyun, and the evolution of US strategy in the post-9/11 world. Despite the continuing existence of detractors 
on both sides, it is tempting to view the alliance, if not its precise nature, as part of the natural order of things. ${ }^{1}$

With this in mind, we believe it useful to reexamine the shaky nature of the relationship of the United States and Korea in the years between World War II and the Korean War. In particular we will examine the attitudes, perceptions, and behavior of the American occupiers of Korea from September 1945 to August 1948, the reaction of the native population and its leaders to the US course, and the impact of the interaction on US policy in the lead-up to the outbreak of war in June 1950. This examination reveals some of the cultural and psychological differences between the two peoples and makes it clear that the alliance between the United States and the ROK was anything but inevitable. We conclude with some observations about how events on the peninsula from 1950 to 1953 impacted the relationship and why the military alliance that emerged in its aftermath has endured.

\section{The Strategic Perspective}

The United States engaged in four military occupations after World War II and the one in Korea was both the shortest and the least successful. When the occupation ended during the second half of 1948, Korea was a divided land with hostile indigenous governments, the USsponsored ROK in the south and the Soviet-sponsored Democratic People's Republic of Korea (DPRK) in the north. Each of these governments claimed sovereignty over the entire peninsula and was headed by a man intent upon using whatever means were necessary to make his claim a reality. DPRK leader Kim Il-sung was in a much better position to do so, as his government was in firm control of territory above the 38th Parallel; in contrast, his rival to the south, Syngman Rhee, faced substantial and growing internal turmoil.

The DPRK's advantage reflected the relatively more successful Soviet occupation of the north than that of the United States in the south, at least for the short term. The Soviet zone possessed only half the population of the American and, from the start, the Soviet occupiers exercised a firm hand, immediately displacing Japanese colonial personnel, who had ruled the peninsula since 1910, supporting antiJapanese natives, mostly exiles sympathetic to a revolutionary course, and then executing broad land reform. Uncooperative natives were either suppressed or pushed southward into the US zone.

\footnotetext{
${ }^{1}$ For a persuasive, largely optimistic analysis of the future of the alliance, see Scott Snyder, China's Rise and the Two Koreas (London: Lynne Rienner 2009).
} 
In contrast, the poorly prepared Americans fumbled badly, at first retaining Japanese in positions of authority and then replacing them with Korean collaborators while retaining the colonial structure. Occupation authorities assisted in building an indigenous police force that replicated many practices of its despised Japanese predecessor and generated widespread animosity. The Americans also favored the political Right while encouraging political parties and free market activities, which facilitated neither cohesion nor material prosperity, and delayed extensive land reform until the spring of 1948, then redistributing only Japanese owned properties, a mere quarter of the total in the US zone. The ROK government that emerged in midAugust 1948 was dominated by the far Right and divided between an autocratic President Rhee and a Democratic Party of conservative landowners in the legislative branch, who believed the president should be a figurehead. In November, in the midst of stalemate between the executive and legislative branches in Seoul and expanding unrest in the countryside, US ambassador John J. Muccio wrote home that the new government was 'incompetent' and 'without strong public support'.

The United States was far from firmly committed to stay the course in Korea. During 1947 the Joint Chiefs of Staff had concluded that the United States possessed no strategic interest in maintaining troops on the peninsula and Congress showed little inclination to expend major funds on Korea. ${ }^{3}$ The State Department succeeded in delaying a final withdrawal of US military units, but by the end of 1948 the number of American soldiers there was down to 8,000. Persistent pressure from the Pentagon, combined with some improvement in conditions below the 38th Parallel, led to their departure in June 1949. Although the United States left behind some military equipment and 500 military personnel to assist in training ROK armed forces, Washington declined to make a commitment to South Korea's defense, as it was in the process of doing for Western Europe. What is more, Congress refused to move quickly to pass an economic aid program for the ROK. With the Communists in China marching toward victory in the civil war there, their northern armies manned in part by tens of thousands of

\footnotetext{
${ }^{2}$ US Department of State, F[oreign] R[elations of the] U[nited] S[tates], 1948 (Washington DC: Government Printing Office 1971), 6: 1326.

${ }^{3}$ For the Joint Chiefs' analysis, see FRUS, 1947, 6: 417-18. For the lack of congressional support for a large-scale aid program for Korea, see William Stueck, The Wedemeyer Mission: American Politics and Foreign Policy during the Cold War (Athens, GA: Univ. of Georgia Press 1984), 25-6.
} 
ethnic Koreans well-positioned for redeployment in the DPRK, ROK prospects appeared anything but promising. ${ }^{4}$

How did the United States get to this discouraging point in Korea? The easy answer is that the situation grew out of a combination of the breakdown of US-Soviet relations in the aftermath of World War II, the bumbling of occupation authorities in South Korea, and a strategic reassessment of American interests in Korea in the midst of evolving conditions elsewhere, especially in Europe and the United States. That is, as Washington took on breathtaking and costly new peacetime responsibilities in Europe, Korea looked expendable, if grudgingly so given the confrontation there with the Soviet Union and its proximity to Japan. In the end the peninsula was not vital in terms of resources and Japan could be defended with air and naval power far more cheaply than with US troops on mainland Asia.

This explanation is essential to an understanding of events, but it ignores the context of direct American interaction with the Korean people from September 1945 onward. It is to this factor that we turn our focus.

\section{Not a Pretty Picture: Americans and Koreans Getting to Know Each Other}

US troops began arriving in large numbers in Korea on 8 September 1945, more than three weeks after the Japanese surrender. Over the next month and a half, the numbers rose to about 77,000 , the peak for the occupation period. ${ }^{5}$

By the time American troops arrived, Koreans were deeply engaged in activity aimed at replacing the colonial regime and, they believed, establishing their independence. In mid-August Japanese

\footnotetext{
${ }^{4}$ For an analysis of US policy toward Korea from 1947 through June 1949, see William Stueck, The Road to Confrontation: American Policy toward China and Korea, 19471950 (Chapel Hill: Univ. of North Carolina Press 1981), 75-110, 153-9. For coverage of evolving conditions in South Korea, see Bruce Cumings, The Origins of the Korean War, Vol. 2, The Roaring of the Cataract 1947-1950 (Princeton, NJ: Princeton UP 1990), 185-290, and Allan R. Millett, The War for Korea, 1945-1950: A House Burning (Lawrence: UP of Kansas 2005), 159-85.

' 'H[istory of] US A[rmy] F[orces[ i[n] K[orea]' [henceforth 'HUSAFIK'] Part I, Ch. 6, 69. This unpublished manuscript written by American servicemen attached to the historical office of the US Command in Korea is available in the US Army Center for Military History, Ft McNair, Washington DC and the Historical Office of the US military base at Yongsan, Seoul, Republic of Korea. The organization is erratic, as 'Part' is used both for separate volumes and for sections of chapters. To avoid confusion, we identify the largest organizational category as 'Volume' and a separately labeled section of a chapter as 'Part'.
} 
Governor-General Abe Nobuyuki, anticipating his country's surrender, aware that the Soviets had entered the peninsula after declaring war on 8 August, and fearing that Koreans would respond by attacking the more than 378,000 Japanese civilians and 163,000 Japanese military personnel residing in Korea, moved to engage a native elite in a transitional process that would ensure order. ${ }^{6}$ After a moderate nationalist rejected his overture, Abe approached Yo Un-hyong, a non-Communist Leftist whose demands for freedom of action were reluctantly accepted. Thus in Seoul Yo established the Committee for the Preparation of Korean Independence (CPKI) and began setting up a governmental framework for Korean self-rule. At the local level people's committees sprouted up, often at the behest of the CPKI. These bodies frequently gained backing from native soldiers who had recently deserted the Imperial Japanese Army and armed youth groups (ch'iandae) and private armies that included thousands of prisoners both political and criminal - freed by the CPKI. ${ }^{7}$

Yo sought to recruit people of all political stripes, but most conservatives refused to cooperate, resulting in a Leftist-dominated organization. Korea in those days, according to one authoritative account, was 'a maelstrom of old and new classes, political groups, and ideologies'. Four in five natives farmed for a livelihood, overwhelmingly as tenants. Japanese-directed economic development had added to the mix 'an assortment of capitalists, white-collar professionals, [and] factory wage workers'. Wartime mobilization had produced increasing, often forced, internal migration and a draconian system of assimilation that sought to root out all vestiges of Korean culture, including names and language. While open resistance was impossible, Koreans accommodated their Japanese masters to varying degrees, producing resentments within the native population that promised to surface with liberation. Broadly speaking, political groupings divided into Right and Left.

Most Koreans with property and education had engaged in some collaboration with the Japanese, and they stood on the Right in opposing far-reaching change, such as comprehensive land reform or other instruments for redistributing wealth. Joining them were less educated, less prosperous people who had served in the colonial regime, including in the notorious police force, which was nearly 40 percent Korean.

\footnotetext{
${ }^{6}$ Millett, War for Korea, 43.

${ }^{7}$ Key secondary sources include ibid., 43-52, and Bruce Cumings, The Origins of the Korean War, Vol. 1, Liberation and the Emergence of Separate Regimes 1945-1947 (Princeton, NJ: Princeton UP 1981), 68-100.
} 
On the Left were a variety of groups - intellectuals, peasants, workers, and students - who lay in wait to rise up against the government. Groupings were far from static. On the Left the Communists were the best organized and possessed some connection to the Soviet Union through its Seoul consulate, but they were neither dominant nor initially unwilling to work with others. ${ }^{8}$

By early September Pak Hon-yong, the most prominent Communist in the south, exercised considerable influence in the CPKI and conservatives, anticipating the arrival of American troops, organized a countermovement. On the eve of US arrival, CPKI leaders called a meeting in Seoul of hundreds of sympathizers from the provinces and declared the formation of the Korean People's Republic (KPR). Controlled by Leftists, the meeting nonetheless appointed to top positions several Rightists, including patriots residing abroad such as Syngman Rhee, the most influential fighter for Korean independence in the United States, and $\mathrm{Kim} \mathrm{Ku}$, head of the Korean Provisional Government (KPG) in Chungking. Unfortunately, such appointments occurred without the knowledge or approval of the appointees themselves and at a time when US relations with the Soviet Union were deteriorating. ${ }^{9}$

Leading American troops who entered Korea in September 1945 was Lieutenant General John R. Hodge, the tough, straight-talking, combat-hardened commander of the XXIV Corps. Hodge lacked experience in administration and politics, knowledge of Korea, and detailed guidance from Washington or his immediate superior, General Douglas A. MacArthur, the US Far Eastern Commander and head of the occupation of Japan. His primary understanding of events in Korea was through wire communications with Japanese officials in Seoul, which began on 29 August. Alarmed by the activities of the CPKI and other Leftist organizations and suspecting that the Soviet consulate was advising the Communists, Japanese authorities reasserted themselves while urging the Americans to hasten their arrival. With mounting strikes and assaults on police by Koreans, the Japanese warned of possible attacks on American troops as they landed and suggested a delay in the 'dismemberment of Japanese forces and the transfer of administrative organs from the Japanese hand'. ${ }^{10}$ General MacArthur initially directed Hodge to treat Koreans as 'liberated people' and Hodge's letter to his subordinate commanders of 28 August adopted this view while cautioning them on 'matters of security'. With several

\footnotetext{
${ }^{8}$ Carter Eckert, Ki-baik Lee, Young Ick Lew, Michael Robinson, and Edward W. Wagner, Korea Old and New: A History (Seoul: Ilchokak 1990), 199-236.

${ }^{9}$ Cumings, Origins, 1: 68-100.

${ }^{10}$ 'HUSAFIK', Vol. 1, Ch. 1, 51-2, 57-8, 83-4.
} 
hundred thousand Japanese on the peninsula and Koreans divided into 'several political factions', he warned, the Americans must 'be wary of Oriental favors and on the alert for a double cross'. ${ }^{11}$

A week later, however, General Hodge referred to Korea as 'an enemy of the United States ... subject to the provisions and the terms of the surrender'. ${ }^{12}$ On 1 and 5 September he had leaflets dropped on Seoul, Pusan, and Inchon informing residents of the impending arrival of US troops and urging Koreans to avoid disorder and prepare for a gradual transition from Japanese governance to self-rule. ${ }^{13}$ Profoundly conservative and focused on maintaining order in what seemed to be highly volatile conditions, Hodge devoted little thought to the manipulative aspects of Japanese communiqués deriving from the natural desire to hold on to as much of the peninsula's wealth as possible.

General Hodge's refusal to treat Koreans as 'liberated' was consistent with much thinking in Washington. Prior to the Japanese takeover, Korea had governed itself for over a millennium, but American planners thought the people there required tutelage before enjoying full independence. The declaration at Cairo of the United States, Great Britain, and China in November 1943 that, 'in due course', the peninsula would become 'free and independent' reflected this thinking. ${ }^{14}$ Conscious that Korea's internal turmoil at the turn of the century had helped bring on two wars in northeast Asia and that the Japanese had dominated all the top positions in the government since 1910, American policymakers were disinclined to leave Koreans to their own devices after Japan's defeat. The preferred course, one analysis concluded, was a promise of eventual independence 'after a period of self-government under international trusteeship'. ${ }^{15}$

American planners ignored the consistent stand of Korean exiles against any kind of transition to independence. After Pearl Harbor leaders of the KPG quickly began lobbying for recognition and aid. ${ }^{16}$ Noting the divisions in the KPG and among exile groups in the United

\footnotetext{
${ }^{11}$ Ibid., 67.

${ }^{12}$ Hodge's directive of 4 Sept. 1945, as quoted in Han-mu Kang, 'The United States Military Government in Korea, 1945-1948: An Analysis and Evaluation of its Policy' (PhD diss., Univ. of Cincinnati 1970), 34-5.

${ }^{13}$ 'HUSAFIK', Vol. 1, Ch. 1, 68-71.

${ }^{14}$ Department of State Bulletin 9 (4 Dec. 1943), 393.

${ }^{15}$ N[ational] A[rchives, College Park, MD], [State Department Records] RG 59, Records of Harley A. Notter, 1939-45, box 63, 'Korea: Economic Developments and Prospects', April 1943.

${ }^{16}$ See, for example, report by Roy P. McNair, Jr, 17 Dec. 1942, assistant military attaché to China, in Records of the Department of State Relating to the Internal Affairs of Korea, 1940-44 (microfilm edition), Reel 2.
} 
States, the uncertain roots of the KPG among Koreans at home, the unlikelihood that Koreans could provide any significant assistance to the war effort against Japan, and the complications recognition of the anti-Communist KPG would create with the Soviet Union, the United States never granted recognition. KPG efforts continued, however, giving Americans every reason to believe that Korean exiles, at least those in the United States and Nationalist China, stood as one on immediate independence after the war. ${ }^{17}$

Yet US leaders still talked of a multi-power Korean trusteeship and thought they had agreement in principle of their Soviet and British colleagues for the approach. The war ended more quickly than anticipated and, with the disappearance of common enemies, amid increasing distrust between the United States and the Soviet Union. On the eve of Japan's surrender and with Soviet troops already on the peninsula in the extreme northeast, Washington proposed the 38th Parallel as the dividing line between Soviet and American occupation zones and Moscow quickly agreed, but no agreement existed on Korea's road to independence. The trusteeship approach remained alive in Washington, grounded in the assumption that for the moment Koreans were incapable of governing themselves. That assumption joined with a growing desire to contain Soviet expansion and evolving conditions on the ground in Korea to dictate policy. ${ }^{18}$

Koreans' failure to contribute significantly to the defeat of Japan was also a factor in Hodge's initial actions on the peninsula. The Commanding General's only prior exposure to Koreans had been with the tens of thousands who either had fought in Japan's armies in the Pacific War or had provided much of the labor for them behind the lines. ${ }^{19}$ Within days of his arrival in the country Hodge was widely quoted as referring to Koreans as 'the same breed of cat as the Japanese'. ${ }^{20}$ The quote was inexact and taken out of context, but Hodge's attitudes, not to mention those in Washington, derived in part

\footnotetext{
${ }^{17}$ James I. Matray, The Reluctant Crusade: American Foreign Policy in Korea, 19411950 (Honolulu: Univ. of Hawaii Press 1985), 20-1.

${ }^{18}$ For a recent account of American maneuvering on Korea during the war, see SeungYoung Kim, American Diplomacy and Strategy toward Korea and Northeast Asia, 1882-1950 and After: Perception of Polarity and US Commitment to a Periphery (New York: Palgrave Macmillan 2009), 73-131.

${ }^{19} \mathrm{On}$ the use of Korean manpower by the Japanese during World War II, Richard Frank provided us with key information. For the revealing experience on this matter of a young US Marine officer during the Saipan campaign of 1944, see Gregory Henderson, Korea: The Politics of the Vortex (Cambridge, MA: Harvard UP 1968), 416 n29.

${ }^{20}$ Richard E. Lauterbach, Danger from the East (New York: Harper \& Row 1947), 201; FRUS, 1945, 6: 1135.
} 
from a belief that Koreans had done nothing to earn immediate independence.

Despite Japan's intense wartime propaganda against the United States and the brutal behavior of Soviet troops in the north, American soldiers received an enthusiastic reception from most Koreans. ${ }^{21}$ Due to the actions of Japanese police, Koreans at Inchon on 8 September were subdued as the US 7th Infantry Division began landing in force. ${ }^{22}$ Yet days before hundreds of Koreans residing in villages between Inchon and Seoul had gathered along the route of an advance team of American military police to adorn their vehicles with flowers. ${ }^{23}$ The larger units that followed, one American journalist who accompanied them later wrote, 'were like shining knights descended straight from heaven to strike away a people's shackles'. As American soldiers fanned out across the southern half of the country to assume their occupation duties, they were almost uniformly welcomed as heroes. ${ }^{24}$

The honeymoon was short. Within days of General Hodge's arrival in Seoul, the police were in disarray and the streets seethed with tension. ${ }^{25}$ Soviets in the consulate there were suspected of encouraging agitators and, as one American remarked, were 'the roughest, toughest aggregation of people he had ever seen'. ${ }^{26}$ The State Department representative to the occupation reported 'critical shortages [of] coal and food cereals' and widespread unemployment, in part due to collapse of Japanese war industries, in part because many Koreans had chosen to take 'a prolonged holiday' after the announcement of Japan's surrender. ${ }^{27}$ New York Times correspondent Richard J. H. Johnston,

\footnotetext{
${ }^{21}$ For Korean perspectives, see Sonny Che, Forever Alien: A Korean Memoir, 19301951 (Jefferson, NC: McFarland 2000), 143-6 and Maeil Sinbo, 9 Sept. 1945. For a recent account of the early behavior of Soviet troops in the north, see Ronald $\mathrm{H}$. Spector, In the Ruins of Empire: The Japanese Surrender and the Battle for Postwar Asia (New York: Random House 2007), 143-6.

22'HUSAFIK', Vol. 1, Ch. 4, 6; New York Times, 9 Sept. 1945. See also the recollections of an American officer in 'My Most Memorable Day: Korea, Sept. 8, 1945', Monadnock Ledger, 24 May 2001.

${ }^{23}$ Lawrence E. Gelfand to Yi Boram, 22 Sept. 2005. Gelfand was a member of the unit. See also the description of Col. Brainard E. Prescott, who arrived at Inchon on 6 Sept. 1945 and soon became the Civil Administrator of the occupation, in Department of State Bulletin 24 (27 Jan. 1946), 106.

${ }^{24}$ Harold R. Isaacs, No Peace for Asia (New York: Macmillan 1947), 81-3; see also 'HUSAFIK', Vol. 1, Ch. 6, 10, 15-16, 51-2.

${ }^{25} \mathrm{NA}$, [Records of GHQ Far East Command, Supreme Commander Allied Powers and United Nations], RG 554, Entry A1 1378, box 21, 'Notes on Corps Staff Conference', 13 Sept. 1945.

${ }^{26}$ Ibid.; 'Notes of Staff Conference', 15 Sept. 1945.

${ }^{27}$ FRUS, 1945, 6: 1050-1.
} 
who accompanied US forces entering Korea, remarked that 'here is an unprecedented situation for the Allied liberators'. ${ }^{28}$

The version of the Cairo declaration that circulated in Korea translated the phrase 'in due course' into 'the equivalent of "in a few days"', but General Hodge quickly made it clear that independence would not be granted immediately and that Japanese would be kept in government positions, high and low alike, until Koreans acquired the skills necessary to replace them. He urged Koreans to show patience, to 'demonstrate to the democratic nations of the world and to me as their representative your capacities and abilities as a people and your readiness to accept an honored place in the family of nations' ${ }^{29}$ Historian Bruce Cumings remarks that Hodge's initial actions, combined with the cordial relations apparent between the Americans and Japanese, now 'cooperative, orderly, and docile', suggested that the Americans 'liked the Japanese better than the Koreans', who seemed 'headstrong, unruly, and obstreperous'. ${ }^{30}$ Hodge's announcement created such an uproar among Koreans that MacArthur intervened, leading to the immediate replacement of Governor-General Abe and his top subordinates. ${ }^{31}$

Realizing that Korean sentiment dictated the rapid replacement of Japanese in government positions, General Hodge turned for advice to better educated Koreans who were often Christians, had extensive past experience with Americans, usually through missionaries, and spoke at least some English. The English-speakers often took jobs with the American military government as translators. Unfortunately, Hodge, in part because he was not authorized to recognize an indigenous Korean government, but mostly because he tended to view anyone to the left of center as unreliable, chose to ignore the KPR and to favor conservatives in the KDP, which included many Koreans resented by their countrymen for having done comparatively well under the Japanese. ${ }^{32}$ The result was to reinforce divisions on the peninsula, among Koreans, who needed all the encouragement they could get to cooperate with each other, and between Americans and Soviets, the latter of whom were already well ensconced above the 38th Parallel. While not recognizing the Seoul-based KPR, the Soviets did work extensively with the people's committees at the local level in their zone.

Despite General Hodge's refusal to recognize the KPR or to consult extensively with its members, the group refused to retreat from its claim

\footnotetext{
${ }^{28}$ New York Times, 10 Sept. 1945.

${ }^{29}$ 'HUSAFIK', Vol. 1, Ch. 4, 17; FRUS, 1945, 6: 1049.

${ }^{30}$ Cumings, Origins, 1: 138-9.

${ }^{31}$ FRUS, 1945, 6: 1045.

${ }^{32}$ For example, see 'HUSAFIK', Vol. 3, Ch. 2, 16.
} 
to be a government and it continued to draw considerable support from the local press and the public. In early October, in an effort to undermine the KPR while at the same time showing sensitivity to the need to consult Koreans on a formal basis, the US military governor, Major General Archibald V. Arnold, appointed an Advisory Council of eleven Korean elders, nine of whom were conservatives. ${ }^{33}$ A few days later General Arnold issued a scathing statement ridiculing the pretensions of KPR leaders and the behavior of much of the press, which wrote positively about them and criticized US actions. The remarks were particularly offensive in their use of such words as 'amateur', 'venal', 'self-styled', 'boyishness', and 'puppet' to characterize many Koreans who were of considerable age and stature in a society that placed high value on seniority and 'face'. Adding injury to insult, he ordered newspapers to publish his remarks. ${ }^{34}$ The American occupation's campaign to prop up conservatives continued with efforts to arrange for the return of Rhee from the United States and KPG leaders from China. As a result, Rhee arrived in Korea during the third week of October and top KPG personnel appeared in late November and early December. ${ }^{35}$

As conservatives with reputations in their homeland and lacking any hint of collaboration with the Japanese, these men appeared to Hodge to be potential uniters of Rightist parties in the quest for stability and to squelch the Left. Yet the Commanding General got less than he had bargained for. Both Rhee and Kim Koo proved fiercely independent - of the United States as well as of each other. In particular, Rhee's open antagonism toward the Left and the Soviet Union strengthened the trend toward the division of the peninsula and the polarization of politics below the 38th Parallel. In late November William Langdon, the State Department's political adviser to the occupation, who had served in Korea during the 1930s, wrote home that in the Korean people are certain bad traits that cannot be overcome except by actual experience of their evil consequences: Division, obsequiousness, inordinate self seeking, strong sectional rivalries and intolerance of opposition'. He proposed that the United States move expeditiously toward creating an independent government in Korea and a joint withdrawal of occupation forces. ${ }^{36}$

\footnotetext{
${ }^{33}$ Richard D. Robinson, 'Betrayal of a Nation', 57. This unpublished manuscript was written by a member of the US occupation in the fall of 1947, immediately after he left Korea. It is available at the Harvard-Yenching Library, Cambridge, MA.

${ }^{34}$ Ibid., 55-6; 'HUSAFIK', Vol. 1, Ch. 8, 55-8.

${ }^{35}$ Cumings, Origins, 1: 188-93.

${ }^{36}$ FRUS, 1945, 6: 1131.
} 
By mid-December 1945 General Hodge was so frustrated with conditions in south Korea, a result in his mind of the division of the peninsula into separate occupation zones and the disinclination of most Koreans to cooperate with either each other or the Americans, that he recommended to Tokyo and Washington 'serious consideration to an agreement' for joint foreign withdrawal from the country, thus leaving it 'to its own devices and an inevitable internal upheaval for its self purification'. ${ }^{37}$ Four months later his frustrations boiled over in a report to Tokyo. Koreans were 'the most difficult of all peoples I have ever encountered', he declared. 'Independence' was their 'one common idea', and to them it meant 'that all should be freed from any distasteful work and from any and all restraint on actions or words'. 'Stubborn, ... highly contentious among themselves, ... highly volatile and unpredictable, ... [possessing] low individual integrity ... [and] low capacity for citizenship', they were 'pro self and anti most everything else'. 'Their history as a corruptly governed hermit nation before Japanese domination', Hodge continued, 'plus the years as a slave nation of Japan and the high illiteracy rate, operate[d] greatly against their capacity for competent self-rule in modern times'. '[T]here will be a real blood purge in Korea at some stage of her reestablishment', he predicted, and it could come during the American occupation. 'Pressed hard enough', the Commanding General warned, Koreans 'would happily open guerrilla warfare against occupying troops of any nation'. ${ }^{38}$

This diatribe included elements of truth, but General Hodge ignored the fact that some of his problems were rooted in American missteps, including his early encouragement of political groupings, however small, his disastrous effort to create a free market for rice that produced widespread hoarding and shortages, and Washington's effort against his advice to impose a multilateral trusteeship on Korea. ${ }^{39}$

To his credit, General Hodge initially did not insist on suppression of the people's committees at the local level. American officers in the provinces possessed considerable flexibility to work with those groups, which was often essential in maintaining order given the breakdown in authority of the Japanese police and the limited number of US troops available. ${ }^{40} \mathrm{Had}$ Hodge adopted as a more systematic and sustained policy of cooperation with the people's committees, he would have

\footnotetext{
${ }^{37}$ Ibid., 1148.

${ }^{38}$ As quoted in 'HUSAFIK', Vol. 1, Ch. 1, 143-4.

${ }^{39} \mathrm{On}$ the encouragement of political groups and its impact, see Henderson, Korea, 113-36; on efforts to create a free rice market, see Cumings, Origins, 1: 202-206

${ }^{40}$ E. Grant Meade, American Military Government in Korea (New York: King's Crown Press 1951), 60-1.
} 
greatly reduced the tasks of American forces, tasks made all the more difficult by the need to replace Japanese personnel as rapidly as possible and by the absence until the second half of October 1945 of a sizable group of civil administrators from the United States.

The need to work through local organizations was reinforced by the lack of training for Korea of both the tactical army commands and civil administrators. The latter had received some preparation for Japan, but had been reassigned once MacArthur decided in late September that it would be possible to depend on indigenous personnel there. None of the American administrators knew the Korean language and few knew anything about the people they were now supposed to help govern. E. Grant Meade, a civil administrator assigned to South Cholla province in the extreme southwest of the peninsula, later recalled that, in nine months of training prior to his October arrival in Korea, his sole exposure to the peninsula was in one one-hour lecture.

Lack of training aside, Meade estimated that, for reasons of limited intelligence and/or faulty character, over one in three of the men originally assigned to civil affairs were 'more of a liability than an asset'. Arrogance and condescension frequently accompanied ignorance and incompetence in the makeup of Americans in the occupation. ${ }^{41}$

Donald S. Macdonald, another civil affairs officer who wound up in South Cholla, recounted an incident involving a US major who served as commander of the military government in Kwangju, the provincial capital. One day a group of Koreans visited his office to suggest the name of a man to serve as the city's mayor. The American replied indignantly, 'Mayor? You must be kidding. We came here to kill all you people. $^{, 42}$

Although Koreans lived in a Confucian culture that respected rank, their experiences with US officers poorly versed in their immediate surroundings and often unconcerned about the feelings of those they were charged with governing undermined the authority of the American occupation. ${ }^{43}$ Compounding the problem was the fact that the shortage of adequate officer personnel to serve in positions of authority meant that US enlisted men in their late teens and early twenties often found themselves giving orders to Koreans of considerably greater age and stature in their own communities, a circumstance that caused further strains between occupier and occupied. Such strains became magnified

\footnotetext{
${ }^{41}$ Ibid., $48-51$.

${ }^{42}$ Macdonald Oral History, 'Frontline Diplomacy', < http://memory.loc.gov/ammen/ collections/diplomacy/>.

${ }^{43}$ See, for example, Chon Suk-hi, 'Memory of August 15, 1945: Oral History of Forty Koreans' (Seoul: Hangilsa 2005), 109-10.
} 
in early 1946, when Hodge began campaign to dismantle the people's committees. $^{44}$

From the start the behavior of many rank-and-file US soldiers helped to erode Korean confidence in the occupation. Prior to 1945 the direct experience with Americans of most Koreans had been with the hundreds of missionaries who had flocked to the peninsula from the mid-1880s onward, and that experience had been largely positive. ${ }^{45}$ US soldiers during the occupation, however, were a very different breed than the missionaries. One of the sources of their misbehavior, General Hodge would claim in early 1947, was the rapid replacement of 'those splendid combat soldiers' who had defeated the Japanese with poorly trained 'replacement troops who never fired a shot at the enemy'. ${ }^{46}$ The 7th, 40th, and 6th US Army Divisions that occupied Korea did experience considerable turnover in the months leading up to September 1945, in part because they suffered substantial casualties in fighting the Japanese in Okinawa or the Philippines and required replacements, in part because the most battle-hardened infantrymen who survived were the most likely to be released from service first once the war ended. Even so, many American soldiers who entered Korea in September and October 1945 had fought the Japanese and the behavior of some of them was far from exemplary. ${ }^{47}$

By December 1945 most of the specific acts with which the US command contended as the occupation proceeded - open expressions of disrespect toward Koreans, lack of care in avoiding Korean pedestrians while driving American military vehicles, offensive advances toward Korean women, looting and larceny - were common. Brigadier General Donald J. Myers observed that, while there were always 'a few men with criminal tendencies' who discredited 'thousands of conscientious and trustworthy soldiers', many others made 'false step[s]' that led to courts-martial. He cited two men he had interviewed recently, one of whom 'had robbed a Korean of a worthless wristwatch', the other of whom had stolen 'a few worthless Japanese yen'. One of them had a wife and child in the United States, the other

\footnotetext{
${ }^{44}$ Meade, American Military Government, 8.

${ }^{45}$ Young Ick Lew, Byong-kie Song, Ho-min Yang, and Hy-sop Lim, Korean Perceptions of the United States: A History of Their Origins and Formation, trans. Michael Finch (Seoul: Jimoondang 2006), 1-306.

${ }^{46}$ RG 554, Entry A1 1370, box 50, 'Message from the Commanding General, US Armed Forces in Korea', attached to Col. Charles Ennis, Adjutant General, 'Distribution A', 17 Jan. 1947.

${ }^{47}$ In the 6th Division, for example, many officers and enlisted men who, theoretically, had accumulated enough points to be released immediately after Japan's surrender, were required to go to Korea in late September. See 'HUSAFIK', Vol. 1, Ch. 6, 35.
} 
'a superior combat record'. ${ }^{48}$ In the cases in which official records of courts-martial are available for crimes committed during the first three months of the occupation, two of the soldiers involved in misconduct entered the army in 1942. The entry date for the others remains uncertain. $^{49}$ On 8 December General Hodge wrote to a subordinate in charge of a key area between Seoul and Inchon that he was 'increasingly concerned about the behavior and seeming lack of integrity on the part of our soldiers ..., [including] many of the officer personnel'. In particular he mentioned 'licentiousness', 'hold-ups and robberies', and the acceptance of bribes from Koreans seeking possession of goods in Japanese warehouses. The General believed that such activities were sufficiently widespread to 'jeopardize the success of our occupation'. 50

The fact is that qualities that make a person effective on the battlefield differ substantially from those needed for service in an occupation of foreign peoples, and the experience of war often diminishes any prior feelings of sympathy for others. The experience generally begins in a military training facility in the United States. One veteran of the Pacific War and the Korean occupation described Camp Hood in Texas, his site for basic training in late 1944, as an 'American concentration camp... where young boys were robbed of their innocence and trained to do the killing necessary to finish the war'. He remembered one captain telling his unit that 'my main purpose in life ... is to change your attitude so that you will want to close with the enemy and kill him with your bare hands', and the officer conducted numerous drills to ensure success. ${ }^{51}$

The experience of war reinforced soldiers' training with a vengeance. Journalist Harold R. Isaacs, who spent much of the early 1940s in Asia and the Pacific and accompanied US forces to Korea in September 1945, later wrote that American combatants generally 'did not like' the Asian peoples with whom they came into contact, and the feeling was reciprocated. 'It could hardly have been otherwise', he noted, as 'war in general fosters callousness and indifference to suffering and

\footnotetext{
${ }^{48}$ RG 554, Entry A1 1370, Box 1, Brig. Gen. Donald J. Myers to Col. Edwin A. Henn, 12 Dec. 1945.

${ }^{49}$ The cases are Howard L. Waldron, 5 Nov. 1945, Box 241; Jerry L. Whitecotton, 13 Nov. 1945, Box 241; William J. Smith, 12 Jan. 1946, Box 238; Paul Jones, 24 Jan. 1946, Box 230; all in RG 554, General Courts-Martial.

${ }^{50}$ RG 554, Entry A1 1370, Box 1, Hodge to Maj. Gen. Gilbert R. Cheeves, 8 Dec. 1945.

${ }^{51}$ Russell E. McLogan, Boy Soldier: Coming of Age During World War II (Reading, MI: Terrus Press 1998), 21-2.
} 
death ... [and] grotesquely deforms all human relations'. What is more, the American soldier:

came from a life of gadgets and movies, schools, mass production, more or less good food, cars, juke boxes, radios, and corner drugstores. He was wrenched from all this and plunged abruptly into the midst of primitive misery. He vaguely expected the Orient to be a lush, glamorous, exciting, and somehow mysterious place. What he found was squalor and poverty and degradation.

American combatants had increasing difficulty viewing 'these Asiatics as men and women. Only some subhuman species could live as they did, submit as they did.... Pity usually gave way to indifference, impatience, contempt, and even hatred. ${ }^{52}$

American veterans of the Pacific War who entered Korea in September and October 1945 possessed a sense of achievement for having defeated the Japanese in a prolonged and brutal conflict, as well as an understanding that they were liberating the peninsula from Japan's rule. As Isaacs observed, they had little preparation in their upbringing or education 'to be citizens of the world'. Their notion of themselves as part of a melting pot contributed to their pride, as did the sense that their country possessed 'the most, the best, the biggest, the tallest, the greatest, the finest, the deepest, the superlative in everything', which sheltered them from self-awareness, from the reality of their 'provincial' outlook. 'Profoundly convinced that everything not American is inferior', they regarded their task as achieved and longed to be home, out of the army. Such sentiments impeded empathy. ${ }^{53}$

So did the appearance of Koreans, distinctive in skin color and facial features, diminutive in stature, and clothed in white cotton jackets, pullover tops, and baggy pants tied around the ankles, all without buttons or zippers and with few if any pockets. Add to this the smell of the land, where open sewers flowed through the streets and human feces served as the primary fertilizer, and of the food, the main staple of which, other than rice, was kimchi, a marinated cabbage aged in garlic

\footnotetext{
${ }^{52}$ Isaacs, No Peace in Asia, 7-8. In a survey of early 1944 in Great Britain, American soldiers often expressed shock at the 'backwardness' of the English and their 'lower standard of living', responses that provide insight into how their compatriots in the Pacific theater felt in experiencing the far more primitive conditions there. See NA, [Office of Secretary Defense Records] RG 330, Headquarters, European Theater of Operations, US Army, Research Branch, SSD, Box 1015, 'What American Enlisted Men in England Think of the English', 21 March 1944.

${ }^{53}$ Isaacs, No Peace in Asia, 8-9.
} 
and hot peppers, and American soldiers were well on the way toward an unhappy, contentious sojourn. ${ }^{54}$

Resentful of being held abroad after the war and aware that they were doing Koreans a great favor in removing the Japanese, American soldiers initially tended to be friendly to their hosts, especially children, but they expected deference in return. ${ }^{55}$ When they did not get it - and as time passed they increasingly did not - they responded in a less than kindly fashion. Given the widespread poverty of the native population and the habits built up over two generations of relations with their Japanese masters, many Koreans engaged in petty theft against the occupying troops and their supply depots. Some native women resorted to prostitution to provide income for themselves and their families. While many American soldiers happily availed themselves of this service, they were not deterred from making overt passes at more 'respectable' Korean women, which violated local mores and sparked resentment and sometimes open antagonism in Korean men.

In October a printed warning circulated, revealing both the resentment of Korean men and the receptiveness of some Korean women to the overtures of American men. 'We could not overlook you, womanhood', the English translation of the document began, 'when you fool around with westerners in just showing your vanity and worldly devices, which is nothing but scandalous, while you should put all your strength on establishing the state of new Korea.' It went on to identify several 'scandalous actions' that Korean women were urged to avoid lest they 'be insulted right in front of public' by better behaved Koreans among them. These included 'riding automobiles with westerners', winking and greeting them with friendly words, chewing gum in public, 'whispering to westerners in the night', and going to dance halls frequented by westerners to enjoy 'coffee and chocolate'. ${ }^{56}$ The document illustrates both the restrictiveness of relations between the sexes outside the family among respectable Koreans and the exclusiveness and protectiveness against outsiders of the prevailing

\footnotetext{
${ }^{54}$ For a description of Korean attire, see National Geographic Magazine 88 (Oct. 1945), 436. For examples of American soldiers' reaction to the smell of Korea, see McLogan, Coming of Age, 306; W. L. Dixon, 'Recollections of Korea', Baltimore and Ohio Magazine Aug. 1950, 8-9; and Richard A. Ericson, Jr., Oral History, 'Frontline Diplomacy', < http://memory.loc.gov/ammen/collections/diplomacy/>.

${ }^{55}$ 'HUSAFIK', Vol. 1, Ch. 8, 64.

${ }^{56}$ As quoted in 'HUSAFIK', Vol. 1, Ch. 8, 66. Chon Sang-in, 'haepang kong' ganui sahoesa' [Political geography and social history of Korea, 1945-1950], in Park Chihyang et al. (eds.), haepangchonhusaui/chaeinsik (chaeinsik) [The New Interpretation of Korean History between Liberation and the Korean War], (Seoul: Ch'aeksesang 2006), Vol. II, 159.
} 
insular, patriarchal culture. Rape charges by Koreans against the occupying troops were common, in part because Koreans, at least when American males made passes at native women, defined rape in a manner that involved what they considered inappropriate overtures but not necessarily physical contact. ${ }^{57}$

US occupiers of Germany and Japan behaved much the same way as their countrymen in Korea, but those countries were defeated nations whose people possessed far different psychologies and cultures than Koreans. In Japan, for example, authorities went to considerable lengths to prepare 'comfort facilities' for the sexual gratification of American soldiers once they arrived. To be sure, resentments did develop among Japanese and German males over the aggressiveness of the occupying troops toward native women, but to a significantly lesser degree. In part the depleted male populations in Japan and Germany as a result of the huge war casualties explains this difference. In Korea, in contrast, men were at least as plentiful as women. ${ }^{58}$

If US combat veterans did their fair share to diminish the American reputation with Koreans, they received plenty of help from newer recruits. Certainly they lacked the training and discipline of their predecessors in the Army while possessing all the provincialism and sense of superiority of their older comrades, if not their dehumanizing experience in fighting the Japanese. When in mid-December 1945 Hodge ordered his top subordinates to intensify their educational efforts 'on propriety, behavior and conduct of officers and men' in his command and 'strong punitive action against offenders', the need was manifest among a broad range of soldiers. ${ }^{59}$

\footnotetext{
${ }^{57}$ Lawrence Gelfand to William Stueck, 27 Feb. 2009. Rapes by Western standards did occur and, when reported, sparked considerable outrage among Koreans. In Jan. 1946, for example, four armed GIs raped three Korean female passengers in a railroad compartment while threatening the lives of other passengers. All the perpetrators were captured, tried by court martial, convicted, and sentenced to life imprisonment. For expressions of outrage over the incident in the Korean press, see Choson Ilbo, 10 and 12 Jan. 1946. For the conviction and sentencing, see New York Times, 6 March 1947.

${ }^{58}$ Japanese census reports on Korea from 1940 and 1944 both indicated a slightly larger male population than female. See George M. McCune, Korea Today (Cambridge, MA: Harvard UP 1950), 328. On the interaction of American GIs with German women after the war in the context of a shortage of German men, see Petra Goedde, GIs and Germans: Culture, Gender, and Foreign Relations, 1945-1949 (New Haven, CT: Yale UP 2003). On American GIs and Japanese women, see John Dower, Embracing Defeat: Japan in the Wake of World War II (New York: W.W. Norton 1999), 121-67; on Japanese war casualties, see John Dower, War Without Mercy: Race and Power in the Pacific War (New York: Pantheon Books 1986), 296-9.

${ }^{59}$ In addition to the documents cited in footnotes 44 and 46 above, see RG 554, Entry A1 1370, Box 1, Maj. Gen. C. E. Hudris to Hodge, 14 Dec. 1945.
} 
General Hodge's efforts had limited impact, in part because of an increasing shortage of officers, particularly ones of high character and experience. ${ }^{60}$ In March 1946, in the face of evidence of growing distaste among Koreans about the actions of US soldiers, Hodge again admonished his forces to behave themselves, and even authorized Korean police to apprehend and deliver to American authorities US personnel caught in serious criminal acts. ${ }^{61}$ In November 1946 the Commanding General launched a courtesy drive, among other things listing ten specific acts by American soldiers about which Koreans complained. ${ }^{62}$

Yet persuading - or forcing - American troops to treat Koreans with respect was no easy task. The fact was that what limited interaction had occurred between the average US soldier and low-level officers and the average Korean had not endeared the one to the other. American journalists who visited Korea picked this up immediately. In midOctober 1946, after landing at Kimpo Airport outside Seoul, Mark Gayn was escorted in a 'sedan' into the city by a 'young lieutenant', who 'spoke of the Koreans with contempt' as 'dirty and treacherous'. 'We were watching a flight of [US] fighter planes cavorting over villages to the west', Gayn recorded in his diary. 'The planes dived in a mock attack, re-formed in the sky, and then dived on a new target'. "'Psychological warfare", the lieutenant said. "That's the only way to show these gooks we won't stand for any monkey business".' Late that night, in walking through the streets of Seoul with Roy Roberts, an Associated Press correspondent, Gayn was 'amazed ... [by] the number of drunk Koreans and GIs. I saw an American arguing with a Korean. The soldier was holding the Korean by the lapels of his coat and shouting, "I'll show you, you goddamned gook!"” After intervening to break up the confrontation, Roberts told Gayn, 'such incidents are frequent and generate much resentment against Americans' ${ }^{63}$

At the end of 1946, Walter Simmons of the Chicago Tribune engaged in conversation American military men aboard a ship transporting them from Korea to Japan. 'How do you like Korea?' the GIs in the ship lounge were asked. An army sergeant from Michigan 'snorted' that 'there is as much difference between Japan and Korea as ... between the United States and Japan', and the comparison did not favor Korea.

\footnotetext{
${ }^{60}$ On the shortage of experienced officers, see RG 554, Entry A1 1370, Box 1, Brig. Gen. Donald J. Myers to Col. Edwin A. Henn, 12 Dec. 1945, and Maj. Gen. C.E. Hudris to Hodge, 14 Dec. 1945.

${ }^{61}$ Ibid., Hodge to USAFIK, 3 March 1946, and Hodge to major commanders, 3 March 1946.

${ }^{62}$ See ibid., Box 24, Circular 'Courtesy Drive', 6 Nov. 1946.

${ }^{63}$ Mark Gayn, Japan Diary (Rutland, VT: Charles E. Tuttle 1981), 349, 354.
} 
A private from Oklahoma chimed in that 'the worse you treat the Korean, the more he likes you. The only things they understand are the ball bat and pick handle.' Another private, this time from Pennsylvania, remarked that 'the Japanese are friendly. The Koreans are hostile.... You treat the Korean nice and he cheats you. You leave anything around, and the next minute it is gone'. 'This outpouring ... continued for a long time', Simmons reported, 'and no GI had a kind word to say for the Koreans'. A long-silent army captain eventually confessed to Simmons that 'I've spend over a year in Korea and I am afraid we are failing in the job of making friends with the people. The GI is wrong in some ways, but on the whole I am afraid he is justified in his attitude. ${ }^{64}$

General Hodge's sternest missive to his troops came on 17 January 1947. 'I get increasing expression from Koreans in all walks of life', he told them, 'to the effect that the American officers and men ... are incurring disfavor ... because of poor behavior and because of their 'superior attitude'. After describing five types of soldier who created a negative image of the United States among Koreans - from ones who 'walk five or six abreast down the street shouldering aside the citizens of the town with great contempt' to 'rapists, murderers, hold-up men, and thieves' - he admonished his troops 'to learn something about Korean customs' and 'to respect them in your dealings with Koreans'. 'Take your shoes off when you enter a Korean's home', he urged, and 'keep your hands off Korean women'. Stop 'laughing at' Koreans, calling them by 'derogatory' names, and treating them as members of a 'conquered nation': 'we are here to help the Korean People not run over them', the commander declared. The Korean 'bows and speaks deferentially because he is polite, not because he is currying favor. He has a long proud history (4,000 years) back of his nationality, and though polite and friendly, he is very proud', Hodge noted. 'Openly misjudging him' produced 'resentment', and if he is pushed too far, 'you'll find yourself on the receiving end of a club, knife, or brickbat'. The General concluded with a plea for self-examination on the part of his troops and for them to 'give a helping hand to the new arrivals as they come in and afterward'. ${ }^{65}$

There is no reason to believe that the behavior of American troops improved dramatically as a result of General Hodge's efforts. One reason was the ongoing poor morale of US soldiers produced by the relatively harsh material conditions they faced. These conditions derived partly from the general poverty of Korea, which was

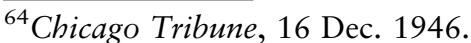

${ }^{65} \mathrm{RG}$ 554, Entry A1 1378, Box 50, 'Message from the Commanding General, US Armed Forces in Korea', attached to Col. Charles Ennis, Adjutant General, 'Distribution A', 17 Jan. 1947.
} 
exacerbated by its ongoing division into occupations zones that were economically complementary but increasingly isolated from each other as relations between the Soviets and the Americans deteriorated. Yet a weak supply system from the United States and within the US zone greatly worsened the problem. Complaints about conditions in Korea from soldiers there and their loved ones at home surfaced before the end of 1945 and grew to such proportions in late 1946 and early 1947 that they drew substantial attention from American legislators.

In September 1946, after visiting US military installations abroad with a group of colleagues, Congressman John Sheridan (Democrat, Pennsylvania), the acting chairman of the House Military Affairs Committee, singled out the American occupation in Korea for criticism. Troop morale there was the lowest anywhere in the world, as soldiers faced conditions in which even fruit juice and toothpaste were luxuries. The politician called for the removal of Hodge from his command. ${ }^{66}$

In early November 1947 an American civilian attached to the US Army in Pusan told journalist Mark Gayn that supplies had improved somewhat in 'some of the bigger towns' after the congressional visit, but were still abysmal in more remote areas. 'This is not a disciplined war army', Gayn was told, but 'a peacetime army of boys 18 and 20, who have had only eight weeks of basic training before they came here'. Little was being done outside the 'big towns ... to keep up their morale. No radios, few movies, little athletic equipment' ${ }^{67}$ Mail from home to US soldiers, which often included food items, was terribly slow in arriving. During the holiday season that followed Gayn's visit, 3,991 bags of mail headed to Korea were lost at sea, a further blow to morale. ${ }^{68}$

The New Year 1947 brought little relief for the American command in Korea. Rhee had arrived in Washington to lobby against US occupation policies and one of his supporters, the energetic Robert T. Oliver, a professor on leave from Syracuse University in upstate New York, informed the State Department that he planned to urge members of Congress to provide no more appropriations to continue military government on the peninsula. ${ }^{69}$ With the executive branch engaged in an in-depth review of US policy toward Korea, General Hodge returned home for consultations. Arriving in Washington in mid February,

\footnotetext{
${ }^{66}$ Lauterbach, Danger from the East, 225.

${ }^{67}$ Gayn, Japan Diary, 409-10.

${ }^{68} \mathrm{NA}$, [War Department Records] RG 165, box 249, 'Letter from a civilian contractor to her family', 25 Dec. 1946.

${ }^{69}$ RG 59, 740.00119 CONTROL (KOREA)/1-2047, Box 3825, Memorandum of Conversation on Korea between Dr Robert T. Oliver and John Z. Williams, 20 Jan. 1947.
} 
Hodge brought with him extensive reports to address the growing correspondence received by the War Department from Capitol Hill complaining about conditions in Korea. 'The primary causes of discontent', one report concluded, ranged from inadequate food - in quality and quantity - a lack of potable water, primitive housing, scarce entertainment, and the limited opportunity to attend church services. The gist of Hodge's response was, as one of his subordinate officers wrote, that 'many of the complaints are ... groundless, beyond the control of this command, [a]natural result of lack of facilities or resources, or ... plain ignorance'. 'The American people have come to accept their comforts and relatively high standard of living', the officer continued, 'without giving thought to the effort that goes into providing those facilities and comforts. The result is a complaining, whining individual when they are not available. ${ }^{70}$

Hodge's reports did not curb the complaints. On 21 March, General Dwight D. Eisenhower, the Army Chief of Staff, wrote to General MacArthur in Tokyo that 'a steadily increasing number of congressional inquiries concerning alleged unsatisfactory conditions in Korea', mostly an outgrowth of letters from soldiers there, might result in a formal investigation by the legislative branch. 'I believe that this matter is [of] sufficient importance to warrant a thorough investigation by your HQ [Headquarters]', Eisenhower advised. ${ }^{71}$

MacArthur, who rarely devoted much attention to Korea, avoided a congressional investigation only by following Eisenhower's advice and dispatching a 'high-powered staff group' to the peninsula. Arriving on 15 March 1947, from the start the group was favorably disposed toward Hodge. But its members conducted a thorough, two-and-a-halfweek tour of the US occupation zone, visiting dozens of bases and interviewing hundreds of officers, enlisted men, and draftees. They concluded that, while earlier in the winter morale had been low, the cause was not poor leadership in Korea; rather it was the arrival as the coldest weather set in of 30,000 inexperienced replacement troops the third major turnover of personnel since September 1945 - most of whom had been seriously misled by army recruiters at home about the conditions they could expect in Korea. Yet despite the erratic 'internal distribution of available stocks', 'a primitiveness in sewage disposal and other sanitary processes', a frequent scarcity of potable water, and the absence of many other amenities available stateside, food was more than adequate, the health of the troops was 'excellent', and their morale was on the upswing. The inspectors reported that 'the majority of

\footnotetext{
${ }^{70}$ RG 554, Entry A11378, Box 83, Col. Charles Ennis, 'Complaints to Members of Congress', 12 Feb. 1947.

${ }^{71}$ RG 554, Entry A1 1370, Box 2, Eisenhower to MacArthur, 21 March 1947.
} 
recent complaints ... coming to ... the War Department and the press through soldiers' letters to their parents ... have exaggerated actual conditions to the point of fantasy and falsity'. Insofar as problems had arisen and continued to exist, responsibility, the inspectors hinted, rested at least as much with the War Department at home as the leadership in the field. ${ }^{72}$

Although the report was not a total whitewash of the occupation, it did diverge sharply from views expressed by many of the soldiers in Korea and their loved ones at home. One letter signed by 11 soldiers, who sarcastically labeled themselves 'Just a bunch of Sissies', was written sometime during the spring of 1947 . This group began by declaring that 'we did not join the army expecting to find a bed of roses. But we did expect to live like civilized people, ... at least as good as the Occupation troops in nearby Japan or Germany.' Self-righteous, yet conscious that their protest would reach at least some unsympathetic eyes, they queried, 'Is it expecting too much to desire a shower more than once in four weeks? Is it expecting too much to have as our only recreation to get drunk once in a while? ... Is it being a Sissy to expect to have your blackest washed once in seven months?' This was merely the beginning of a litany of complaints: 'the mail service stinks', 'most of the food isn't fit for dogs', there are no 'light bulbs or brooms for our huts', and medical care is sparse and delinquent. ${ }^{73}$

Fred Ottoboni, a 19-year-old from Santa Rosa, California, who arrived in Korea in January 1947 and was stationed outside Kunsan on the west coast nearly 200 miles via rail and road from Seoul, noted a half-century later that by springtime his normal weight of 150 pounds, at which he 'had been called skinny', was down to 120. Food had become increasingly scarce as supplies had not kept up with the influx of soldiers into the base. Overall, conditions were so bad that in early March a group of soldiers in the camp briefly 'staged what might be called a mutiny'. Ottoboni sympathized with the mutineers, although he confined his complaints to conversations with fellow soldiers and letters home to his mother, who complained to the War Department. ${ }^{74}$ A group of mothers from Dearborn, Michigan, also lodged a complaint. Just because Korea 'is supposed to be the end of the supply

\footnotetext{
${ }^{72}$ The report is quoted extensively in Col. Charles H. Donnelly, 'Autobiography', 86971, unpublished manuscript, US Military History Institute, Carlisle Barracks, PA, Donnelly Papers.

${ }^{73}$ RG 554, Entry A1 1370, Box 2, Attachment to Hodge to Maj. Gen. Floyd L. Parks, 8 June 1947.

${ }^{74}$ Fred Ottoboni, Korea Between the Wars: A Soldier's Story (Sparks, NV: Vincente Books 1997), 128-33. The only point on which Ottoboni's account disagrees with that of the 'Sissies' is medical care, which Ottoboni considered adequate and timely.
} 
line is no excuse for lack of properly prepared food and the necessary medical attention for the boys there', they asserted. They went on to question the need for the United States to maintain troops on the peninsula: 'Why can't the Korean occupation forces be recalled?'75

To most Americans who had even heard of the occupation of Korea, the answer to that question was far from obvious. American troops sent to that country understood little more, except that the United States was liberating it from Japan. By 1947 the Japanese in Korea had returned home, thus making US purposes all the more dubious.

The 'Sissies' and mutineers among American troops in Korea, though vocal, represented a distinct minority. True, most soldiers lacked the discipline of those in the wartime army, had enlisted to become eligible for GI benefits, and had been misled by recruiters regarding the conditions to expect in service abroad, particularly in Korea. ${ }^{76}$ Yet they had grown up during the Great Depression, many of them on farms on which amenities such as electricity, indoor plumbing, and bountiful food were exceptions and hard work an everyday routine. Carl Vipperman, an 18-year-old from West Virginia, was one such recruit, arriving in Korea in January 1947 on a 16-month tour. Stationed in a rural area not far from the 38th Parallel, he reflected in 2008 that he and his fellow soldiers considered their sojourn 'a great adventure'. Conditions were rugged, of course, but not altogether unlike their childhood experiences. His strongest negative memory was of treatment at the hands of some officers, who often behaved as 'horse's asses'. ${ }^{77}$

In fact, the poor quality of officers at the unit level and above, if not at the top, was more the rule than the exception in Korea. Ottoboni recalled that most of the young men with whom he enlisted already had graduated from high school and wanted to attend college, but needed government assistance through the GI bill to do so. They 'were curious young adults who thought a great deal about many things', he wrote in his memoir, and they were taken aback by 'an almost total lack of communication between the people in charge and the enlistees about the what, where, and why of our

\footnotetext{
${ }^{75}$ RG 554, Entry A1 1370, Box 2, 'Communistic Letter from “Moms” of America', [undated].

${ }^{76}$ In the aftermath of the Japanese surrender, local draft boards often failed to meet their quotas, thus placing pressure on army recruiters to entice young men to enlist. See unpublished manuscript in the Office of the Chief of Military History, Ft McNair, Washington DC, OCMH-66, 'The All-Volunteer Army of 1947-1948'.

${ }^{77}$ Stueck interview with Carl Vipperman, 29 July 2008. Vipperman subsequently used his GI benefits to pursue a higher education, including a $\mathrm{PhD}$ in history. Eventually he became a professor of history at the University of Georgia.
} 
tour of duty'. Concerned about their poor training at home, they questioned early on in their stay in Korea if the Army was 'serious about anything'. The poor management of supplies and equipment in transit, they came to realize, was a notable source of the shortages that produced their discomfort. On the 30-mile trip by truck on bumpy dirt roads from the railroad station in Ili to the base outside Kunsan, for example, many of the soldiers' duffel bags were poorly stored and lost, leaving many of the men with inadequate clothing to maintain warmth or good hygiene through the cold Korean winter. Later, in a visit to Kunsan, Ottoboni and others in his unit purchased from Koreans a variety of food items of US Army origin, an indication that many of the supplies that entered Inchon, their main port of entry, did not reach their intended destination. The reason? They were stolen by Koreans or sold by American supply officers and soldiers to Koreans for resale on the black market.

Resentments in the rank-and-file in rural areas built up as well over the superior lifestyles of the officers that commanded them, not to mention over that of the soldiers fortunate enough to be stationed in the Seoul area. Rumor had it that General MacArthur's command in Tokyo made sure that the best officers sent to the western Pacific went to Japan and that those who performed poorly there often wound up in Korea. ${ }^{78}$ Historical records suggest the truth of the rumor. ${ }^{79}$ Furthermore, as the occupations proceeded word spread among officers in the United States that there were three things to avoid if sent to the western Pacific, 'gonorrhea, diarrhea, and Korea', so the more resourceful and better connected ones undoubtedly maneuvered to avoid being assigned to the peninsula. ${ }^{80}$

Although overt malcontents represented a small minority of American soldiers in Korea, they did make the occupation more difficult to sustain. As General Hodge remarked in one of his letters to critics in the United States, 'each of them makes a noise like a pig under

\footnotetext{
${ }^{78}$ Ottoboni, Korea Between the Wars, 78-9, 85, 129-30, 140, 146-7.

${ }^{79} \mathrm{On}$ the poor general quality of officers in Korea and/or the inclination of the Tokyo command to keep the best in Japan, see RG 554, Entry A1 1370, Box 2, Paul S. Anderson to Hodge, 27 June 1947; Box 1, Hodge to Maj. Gen. Cheeves, 8 Dec. 1945; Box 1, Brig. Gen. Donald J. Myers to Col. Edwin A. Henn, 12 Dec. 1945; Box 2, Hodge to major commanders, 3 Jan. 1948. See also Lauterbach, Danger from the East, 223-4; Meade, American Military Government in Korea, 87-9; William C. Sherman Oral History, 27 Oct. 1993, 3, 'Frontline Diplomacy', < http://memory.loc.gov/ ammen/collections/diplomacy/>; and Robert Smith, MacArthur in Korea: The Naked Emperor (New York: Simon \& Schuster 1982), 18.

${ }^{80}$ The quoted phrase was allegedly uttered publicly by Hodge as a widespread perception in Japan in Nov. 1947. See Harry G. Summers, 'The Korean War: A Fresh Perspective', Military Affairs, April 1996, 2.
} 
a gate', and that noise clearly reached Capitol Hill. ${ }^{81}$ After a series of flare-ups during the first half of 1947, Hodge's efforts to orient troops once they arrived in Korea and his and the Pentagon's public relations measures directed at concerned citizens in the United States appear to have reduced overt discontent among US soldiers on the peninsula. ${ }^{82}$

Negative reports from higher-ups on the behavior of Korean political elites joined with complaints from the field by rank-and-file soldiers to provide an important context within which the Pentagon pressed for an early end to the occupation and a final withdrawal of US troops and Congress proved reluctant to appropriate funds to sustain what were considered minimal American interests in Korea. ${ }^{83}$ Rhee and his allies maneuvered furiously from early 1946 onward to prevent an agreement between the United States and the Soviet Union to end the artificial division of Korea, which they feared would doom the peninsula to domination by the Communists. By the middle of 1946 they were campaigning for creation of an independent government in the south, and this campaign often included advocacy of a joint withdrawal of foreign troops. Hodge tried to counter the campaign. For example, in January 1947, amid growing agitation among Koreans and discontent among his own troops, he issued a press release defending US policy and asserting that his country remained determined to stay 'to bring about the unification of a free and democratic Korea'. Despite his own private reservations, he defended the agreement on Korea made at Moscow in December 1945 by the Soviet, American, and British foreign ministers. While including the possibility of a multipower trusteeship, the agreement called for a joint Soviet-American commission to create a united Korean provisional government. Through this decision, Hodge asserted in a none-to-subtle reminder of the circumstances leading to Japan's departure, 'the Allied Powers assured the world that [the] blood, lives, and resources expended by them in making possible ... [Korean's liberation] would not be wasted, and that Korea would be independent'. He scolded the 'certain elements' who, 'through lack of knowledge or through malicious intent', were deceiving the people in 'creating the impression that the United States now favors and is actively working toward a separate government in

\footnotetext{
${ }^{81}$ RG554, A1 1370, Box 2, Hodge to Cecil Brown, 10 June 1947.

${ }^{82}$ Much of the effort by Hodge and his command is documented in correspondence in ibid., Boxes 1-3. Hodge also wrote 'With the US Army in Korea', which appeared in the June 1947 issue of the popular magazine National Geographic, 829-40.

${ }^{83}$ Gen. William O. Reeder, an army supply officer in Washington during this time told Stueck in an interview on 21 Oct. 1974 that the chief reason for the withdrawal of troops from Korea was the constant complaints of American soldiers and their loved ones to the Pentagon and Congress.
} 
Southern Korea'. ${ }^{84}$ Hodge's efforts came to naught. Because a Communist Korea was also anathema to the United States, it refused to suppress the Rhee forces and eventually executed a plan that in August 1948 left them in a dominant position in an independent government below the 38th Parallel.

Yet the weakness of that government relative to the emergent regime in North Korea now led Rhee to lobby for the continued presence of US Army units. His campaign came to a head in May 1949, when the US State Department finally ended its resistance to Pentagon efforts to remove the remaining American troops. On 7 May the ROK government released a statement that sought either the continued presence of those forces or a public assurance of US protection against outside attack. In this quest the statement distorted the circumstances under which the country had become divided, implying that it was the fault of the United States that Communists were in Korea and threatened the ROK and omitting the role Rhee had played in sabotaging the American effort to reach agreement with the Soviets on creation of a national provisional government. ${ }^{85}$ ROK leaders received neither a reversal of the decision to withdraw forces nor an assurance of protection. Rather, US diplomats warned them that they must do more to put their own house in order, including a buildup of their own army, and to avoid provocations along the tense 38th Parallel boundary, where skirmishes between the ROK and DPRK armies were commonplace. When the ROK ambassador in Washington noted with concern to American officials that the United States was distancing itself from the Nationalist government in China as the Communists advanced there, he was told that South Koreans should learn from that case that US aid could not stem the Communist tide unless indigenous forces put up a stiff resistance. ${ }^{86}$

Among other things, the exchange revealed the deep psychological chasm existing between officials of the two governments. On the one hand were people representing the richest, most powerful nation on earth, who were attempting to cobble together a new global order in the face of concerted opposition from without and only limited acquiescence from many of their countrymen. To US officials dealing with Korea, ROK leaders were a contentious, willful group that showed little appreciation for the American role in freeing their country from Japan, had enormously complicated the American task in the

\footnotetext{
${ }^{84}$ Department of State Bulletin, 19 Jan. 1947, 128.

${ }^{85}$ FRUS, 1949, 7: 1011-12.

${ }^{86}$ See documents in ibid., 1013-21; also Ambassador Muccio's oral history at the Harry S. Truman Library, Independence, MO. Muccio gave a similar account in his interview with author Stueck on 27 Dec. 1973 in Washington DC.
} 
recent occupation, and now presided over a corrupt, autocratic, and often inept government facing active resistance from a significant portion of the South Korean populace. That regime constantly sought aid, resisted any strings attached, and attempted to maneuver the United States into an open-ended commitment to its survival. Such a pledge was out of the question, not the least because it might encourage ROK belligerence toward the North - unnecessarily provoking a conflict that was contrary to American interests - and/or discourage the government from pursuing domestic policies that would broaden public support and enhance prospects for economic development. Under the circumstances, the overt ROK campaign for a clear US commitment simply underscored its absence, thus undermining a more modest effort to deter an outside attack.

On the other hand were people from a small nation that had for centuries sought to isolate itself from the outside world. It had largely succeeded in doing so through a loose attachment to a benevolent, unobtrusive China, in the Confucian worldview its 'elder brother'. In the late nineteenth century Korea was dragged unwillingly into relations with the larger world, was fought over by the three great powers surrounding it, and then, early in the twentieth century, was conquered by the strongest among them. Their country too weak to win independence on its own, Korean exiles sought the assistance of stronger powers, but divided over their preferred patron. When they finally escaped the Japanese grasp in 1945, it was at the price of occupation by two other great powers, both of whom held interests and perceptions that conflicted with Koreans' desire for immediate independence. In the end, those who became ROK leaders chose to postpone unity so as to grasp independence under conditions in which they dominated half the country. Having achieved that objective, partly through manipulation of the United States, they found themselves in the uncomfortable position of resenting their sponsor for its condescension and its failure in 1945 to prevent Soviet entry into the North, yet expecting it to play the 'elder brother' role in providing protection against hostile outside forces. ${ }^{87}$

Given those divergent perspectives, it hardly should be surprising that the United States failed to employ measures adequate to deter an outside attack on the ROK. Even Ambassador Muccio, a patient diplomat more sympathetic than most Americans to South Korean leaders, was distrustful enough to ensure that the allocation of US military aid to the ROK was sufficiently piecemeal to discourage adventurism toward the North. ${ }^{88}$ In the summer of 1950, the strong

\footnotetext{
${ }^{87}$ Lew et al., Korean Perceptions of the United States, 315-18.

${ }^{88}$ Stueck interview with Muccio, 27 Dec. 1973, Washington DC.
} 
American response to the DPRK military offensive derived more from concern about its potential impact on the reputation of the United States worldwide than on sympathy for ROK leaders or the Korean people. ${ }^{89}$

\section{Creating and Sustaining an Alliance}

It would be a distortion to suggest that the Korean War completely transformed the attitudes toward each other of the peoples or policy elites of the United States and South Korea. Evidence is not hard to find after 1953 to demonstrate continuing condescension, frustration, and even disdain on the part of Americans toward South Koreans. Nor is it difficult to unearth evidence of resentment, outrage, and resistance among South Koreans toward their allies across the Pacific. Yet such feelings did not influence the relationship to the degree that they had during the American occupation from 1945 to 1948, and this is the case even though the firing stopped in July 1953 with over 300,000 American troops on the peninsula, a figure that declined to under 60,000 three years later but then held at over 40,000 until the late 1970 s, at 37,000 until the second Bush administration, and now has stabilized at around 27,000. The second American occupation of Korea that began in July 1950 in response to the North Korean attack proved more acceptable to both sides than the first. The question is, why?

The answer is in some ways straightforward. Unlike during the first American occupation, South Koreans now possessed their own government. The ROK grudgingly conceded elements of its sovereignty to accommodate foreign soldiers on its soil and confronted often unwelcome advice on their political, economic, and military affairs, but these paled by comparison to the humiliation of being lectured to by General Hodge and his subordinates on the need for patience on the road to self-government. Furthermore, for over three years the United States had fought side-by-side with South Koreans to defend the ROK, providing massive materiel support and suffering over 150,000 casualties. South Koreans had seen the result of the US withdrawal in 1949, they appreciated the American willingness to help save them from 1950 to 1953, and they understood that a continued US presence, both for military protection and for economic recovery, was essential for their continued survival. The United States had finally played the role of elder brother to the Koreans and its sacrifices had raised the peninsula to a significance in US strategy that was unthinkable prior to June 1950. The ROK and its people were taken far more seriously in

${ }^{89}$ Stueck, Road to Confrontation, 185-90. 

Washington than ever before, and they knew and appreciated the
fact. $^{90}$

The psychology on the American side shifted as well, partly because the sacrifices of war had been shared, partly because Korea had become a major theater in the Cold War. While Koreans had contributed little to their liberation from the Japanese, the ROK Army played an essential role in defending the Pusan perimeter against the North Korean onslaught in August 1950 and by the end of the war manned over 70 percent of the front line units in the United Nations Command. Between 1950 and 1953, the ROK Army suffered over three and onehalf times the battlefield deaths of US armed forces. ${ }^{91}$ In addition, the war produced a major growth in US military preparedness and, with Korea now enjoying a far higher priority among American officials and the public, the most competent and ambitious members of the armed forces had little reason to avoid service there. ${ }^{92}$ Not only could they anticipate major support from home if sent to the peninsula; they could be confident that service in Korea was a likely stepping-stone to careeradvancement. Thus morale among American soldiers in Korea never reached the depths after the war that it had during the first occupation, and the level of competence and efficiency was much higher.

To be sure, the United States remained a country with more than its share of racial prejudice and sense of cultural superiority. If insensitivity toward Koreans on the part of American soldiers gradually diminished during the second occupation, it never disappeared. During the 1980s, anti-Americanism surfaced as never before in South Korea,

\footnotetext{
${ }^{90}$ For an elaboration on this point, see William Stueck, Rethinking the Korean War: A New Diplomatic and Strategic History (Princeton, NJ: Princeton UP 2002), 192-206. ${ }^{91}$ John Kie-chiang Oh, 'The Forgotten Soldiers of the Korean War', in Mark F. Wilkinson (ed.), The Korean War at Fifty: International Perspectives (Lexington: Virginia Military Institute 2004), 101-15. Jack Cox, who graduated from West Point in 1949 and served in the Korean War as an army lieutenant from Oct. 1950 to Feb. 1952, recalled recently that he heard all kinds of negative stories about Koreans before he went to the peninsula, including that they would constantly steal from Americans and would never truly be friends with foreigners. He took about three months to develop a positive attitude toward Koreans. The realization that South Koreans really cared about their country, were willing to fight and die for it, and were more often than not willing to police each other to contain pilfering from their foreign benefactors produced the change. Stueck interview with Cox, 26 Nov. 2007, Fayetteville, NC.

${ }^{92}$ In stark contrast to the situation prior to the war, 'by 1953', historian Steven Casey concludes, 'South Korea could count on an enormous amount of sympathy inside the United States'. See Steven Casey, Selling the Korean War: Propaganda, Politics, and Public Opinion 1950-1953 (New York: OUP 2008), 352-3. On Korean War rearmament in the United States, see William Stueck, 'Reassessing US Strategy in the Aftermath of the Korean War', Orbis 53 (Fall 2009).
} 
now well advanced toward a modern economy, populated increasingly by people with little or no direct memory of the Korean War, and still saddled with an autocratic government supported by the United States. Democracy flourished after 1987, of course, but as the first decade of the twenty-first century progressed public opinion polls in the ROK frequently revealed a high level of distrust of and even animosity toward the United States and the presence of its forces on the peninsula. $^{93}$

Yet that presence continues, and is likely to do so indefinitely. Ongoing concerns about regional stability and the security of a small nation surrounded by giants surely provide the major impetus here, but cultural and psychological factors deserve a place in any explanation of the enduring alliance. Failed marriages often occur because one partner changes while the other remains static, or because changes in both partners move in opposite directions. In the cases of the United States and South Korea since the first American occupation, the movement has been more toward convergence than distance. Whether in the smell of the land, the accessibility of the food, or the dress, linguistic range, educational achievements, modes of transportation, production, and entertainment of the people, South Korea has become much more similar to the United States. True, the surface convergence sometimes hides deeper, enduring differences and it has made South Koreans less willing to tolerate American arrogance, either in the behavior of US soldiers on the streets or in the bars of Seoul and other towns and cities in their land or of US generals, diplomats, and politicians in the councils of government.

Still, accompanying the convergence has been a steady if gradual shift in responsibility and power within the alliance - for example, toward granting the ROK justice system control over off-duty US soldiers who break the laws of the land, toward complete ROK control over its own armed forces, and toward ROK assumption of a larger share of the cost of maintaining US forces on the peninsula and of defending military positions on the ground north of Seoul. Indeed, the evolution of power and responsibility within the alliance since the 1960s inspires confidence that the changing psychological and cultural needs of both sides can be adjusted to accommodate the enduring if also changing strategic rationales for the alliance.

\footnotetext{
${ }^{93}$ See, for example, Yoichi Funabashi, The Peninsula Question: A Chronicle of the Second Korean Nuclear Crisis (Washington DC: Brookings 2007), 218; Mike Chinoy, Meltdown: The Inside Story of the North Korean Nuclear Crisis (New York: St Martin's Press 2008), 100, 154-5, 160, 190, 202; Chae-jin Lee, A Troubled Peace: US Policy and the Two Koreas (Baltimore: Johns Hopkins UP 2006), 193, 226-7, 247.
} 


\section{William Stueck and Boram Yi}

\section{Bibliography}

Casey, Steven, Selling the Korean War: Propaganda, Politics, and Public Opinion 1950-1953 (New York: OUP 2008).

Che, Sonny, Forever Alien: A Korean Memoir, 1930-1951 (Jefferson, NC: McFarland 2000).

Chinoy, Mike, Meltdown: The Inside Story of the North Korean Nuclear Crisis (New York: St. Martin's Press 2008).

Chon Sang-in, 'haepang kong' ganui sahoesa' [Political geography and social history of Korea, 1945-1950] in Park Chi-syang et al. (eds.), haepangchonhusaui chaeinsik (chaeinsik), [The New Interpretation of Korean History between Liberation and the Korean War] (Seoul: Ch'aeksesang 2006).

Cumings, Bruce, The Origins of the Korean War, 2 vols. (Princeton, NJ: Princeton UP 1981 and 1990).

Dixon, W.L., 'Recollections of Korea', Baltimore and Ohio Magazine, Aug. 1950, 8-9.

Dower, John, War Without Mercy: Race and Power in the Pacific War (New York: Pantheon Books 1986).

Dower, John, Embracing Defeat: Japan in the Wake of World War II (New York: W.W. Norton 1999).

Eckert, Carter, Ki-baik Lee, Young Ick Lew, Michael Robinson, and Edward W. Wagner, Korea Old and New: A History (Seoul: Ilchokak 1990).

Funabashi, Yoichi, The Peninsula Question: A Chronicle of the Second Korean Nuclear Crisis (Washington DC: Brookings 2007).

Gayn, Mark, Japan Diary (Rutland, VT: Charles E. Tuttle 1981).

Goedde, Petra, GIs and Germans: Culture, Gender, and Foreign Relations, 1945-1949 (New Haven, CT: Yale UP 2003).

Henderson, Gregory, Korea: The Politics of the Vortex (Cambridge, MA: Harvard UP 1968).

Isaacs, Harold R., No Peace for Asia (New York: Macmillan 1947).

Kang, Han-mu, 'The United States Military Government in Korea, 1945-1948: An Analysis and Evaluation of its Policy' (PhD diss., Univ. of Cincinnati 1970).

Kim, Seung-Young, American Diplomacy and Strategy toward Korea and Northeast Asia 18821950 and After: Perception of Polarity and US Commitment to a Periphery (New York: Palgrave Macmillan 2009).

Lauterbach, Richard E., Danger from the East (New York: Harper \& Row 1947).

Lee, Chae-jin, A Troubled Peace: US Policy and the Two Koreas (Baltimore: Johns Hopkins UP 2006).

Lew, Young Ick, Byong-kie Song, Ho-min Yang, and Hy-sop Lim, Korean Perceptions of the United States: A History of Their Origins and Formation, trans. by Michael Finch (Seoul: Mimoondang 2006).

McCune, George M., Korea Today (Cambridge, MA: Harvard UP 1950).

McLogan, Russell E., Boy Soldier: Coming of Age During World War II (Reading, MI: Terrus Press 1998).

Matray, James I., The Reluctant Crusade: American Foreign Policy in Korea, 1941-1950 (Honolulu: Univ. of Hawaii Press 1985).

Meade, E. Grant, American Military Government in Korea (New York: King's Crown Press 1951).

Millett, Allan R., The War for Korea, 1945-1950: A House Burning (Lawrence: UP of Kansas 2005).

Oh, John Kie-chiang, 'The Forgotten Soldiers of the Korean War', in Mark F. Wilkinson (ed.), The Korean War at Fifty: International Perspectives (Lexington: Virginia Military Institute 2004). Ottoboni, Fred, Korea Between the Wars: A Soldier's Story (Sparks, NV: Vincente Books 1997). Smith, Robert, MacArthur in Korea: The Naked Emperor (New York: Simon \& Schuster 1982). Snyder, Scott, China's Rise and the Two Koreas (London: Lynne Rienner 2009). 
Spector, Ronald H., In the Ruins of Empire: The Japanese Surrender and the Battle for Postwar Asia (New York: Random House 2007).

Stueck, William, The Road to Confrontation: American Policy toward China and Korea, 19471950 (Chapel Hill: Univ. of North Carolina Press 1981).

Stueck, William, The Wedemeyer Mission: American Politics and Foreign Policy During the Cold War (Athens, GA: Univ. of Georgia Press 1984).

Stueck, William, Rethinking the Korean War: A New Diplomatic and Strategic History (Princeton, NJ: Princeton UP 2002).

Stueck, William, 'Reassessing US Strategy in the Aftermath of the Korean War', Orbis 53 (Fall 2009).

Summers, Harry G., 'The Korean War: A Fresh Perspective', Military Affairs, April 1996.

US Department of State, F[oreign] R[elations of the] U[nited] S[tates], 1948 (Washington DC: Government Printing Office 1971). 